\title{
The Habitats, Burrowing Behavior, Physiology Adaptation and Life Cycle of Spadefoot Toads (Pelobates syriacus, Boettger, 1869) at the Southern Limit of Its Distribution in Israel
}

\author{
Gad Degani1,2 \\ ${ }^{1}$ Faculty of Science and Technology, Tel Hai Academic College, Tel-Hai, Israel \\ ${ }^{2}$ MIGAL-Galilee Research Institute, Kiryat Shmona, Israel \\ Email: gad@MIGAL.org.il
}

Received 13 March 2015; accepted 31 May 2015; published 4 June 2015

Copyright (C) 2015 by author and Scientific Research Publishing Inc.

This work is licensed under the Creative Commons Attribution International License (CC BY).

http://creativecommons.org/licenses/by/4.0/

c) (i) Open Access

\begin{abstract}
The present study describes the habitats, life cycle, larvae growth, burrowing behavior and terrestrial adaptation of Spadefoot toads in Israel based on observations and data collected during more than 30 years in northern Israel. The distribution area in Israel is from the north in the Upper Galilee and Golan Heights (annual rainfall range of $500-1000 \mathbf{~ m m}$ ) to the southern coastal plain (annual rainfall of about $250 \mathrm{~mm}$ ). Among the 51 different breeding places of amphibians, only ponds where water was available for a few months were used by Spadefoot toads and metamorphosed populations were found around these ponds. The larvae underwent metamorphosis during the summer and autumn in northern Israel, and during the spring in central and southern Israel. A negative correlation exists between the percentage of toads burrowing and soil moisture levels, with greater burrowing behavior occurring under dry conditions. The plasma concentration increased during burrowing by electrolytes and urea accumulations. The burrowing behavior helped Spadefoot toads survive in this area at the southern border of its distribution.
\end{abstract}

\section{Keywords}

Breeding Places, Burrowing Behavior, Larvae, Life Cycle, Pelobates syriacus, Plasma Concentration 


\section{Introduction}

The knowledge of the biology, ecology and genetics of Spadefoot toads (Pelobates syriacus) in Israel at the southern border of its distribution is important for understanding their adaptation to this area. This species is found in the southeastern Balkans, eastern to southeastern Transcaucasia, northern Iran, and south of the Levant [1]. Spadefoot toads are studied extensively in Europe. The populations are found around breeding places where the substrates of terrestrial habitats include sandy soils, heath lands and deciduous woodlands with loamy soils, while the spawning biotopes include a variety of permanent or semi-permanent ponds [1] [2]. Spadefoot toads were 7.4 years old on average (maximum age recorded 12), despite the fact that sexual maturity (i.e., the age of the youngest adults observed) was reached at a similar age [1] [2]. The size of the egg clutches varied from less than 1000 to almost 6000 eggs, with an average value of 2800 eggs per clutch [2].

The distribution, habitat and breeding place selection of ponds are related to water availability during the spring and early summer in Israel [3], larval growth and complete metamorphosis [4] [5], burrowing behavior [6], physiology adaptations to various environments [7], and biology [8] [9]. The burrowing toad P. syriacus spends 8 - 10 months of the year being buried in soil (Warburg, 1971, 1972). During the summer, the soil dries out, and the osmotic relationship between the toad and the surrounding soil changes. At a certain point, water begins to pass from the toad to the soil (or the air) and the toad becomes dehydrated.

Spadefoot toads are highly specialized and have a narrow ecological niche that selects lower levels of diversity [10]. The genetic variation among their populations was studied in the southern area of the Mediterranean shoreline [11] [12]. Nevo [13] suggested that Pelobates was best explained by the environmental variability model based on selection for homozygosity as an adaptive strategy in the relatively constant and narrow subterranean niche. Although several aspects of Spadefoot toads in Israel have been studied, the life cycle of Spadefoot toads at the southern border of its distribution in Israel has not been described in detail. Due to their secretive behavior (nocturnal activity, weak underwater breeding call and cryptic coloration), their life histories are not well documented, and overall there is a scarcity of information regarding this genus. Moreover, this genus, Pelobates, is distributed in different climates, which affects life cycle, and some basic biological characteristics are similar and might help to complete the information of the species in Israel, Pelobates syriacus.

The purpose of the present study is to describe the habitats, life cycle, larvae growth, burrowing behavior and terrestrial adaptation of Spadefoot toads in Israel based on observations and data collected during more than 30 years in northern Israel.

\section{Materials and Methods}

\subsection{Study Area}

The study was carried out over four consecutive decades (1979-2014). Different aquatic habitats were dispersed over an area of approximately $1400 \mathrm{~km}^{2}$ in northern Israel. The habitats included springs and streams that were stable water bodies where water was available year-round, rock pool holes, which were filled by rainwater and whose hydroperiods were long (about $200 \mathrm{~d} / \mathrm{yr}$ ), and ponds, which were flooded during the autumn when rainfall began, and gradually dried out between the late winter months and early summer.

\subsection{Sampling}

The water body was examined by nets (pore size $450 \mu \mathrm{m}$ ) from a depth of approximately $10-30 \mathrm{~cm}$, as described previously by [3]. Rain pools and ponds in Israel that were filled by rain held the water for 3 - 4 months before drying up; large ponds dried up after a period of $6-12$ years. The elevation of the breeding places is between 0 to $1000 \mathrm{~m}$ above sea level. The breeding places that were examined are presented in Table 1 and Figure 1.

\subsection{Biotic and Abiotic Water Parameters}

Water quality testing during larval growth, which was described in detail in the chapter on water quality, included dissolved oxygen (\%), water temperature $\left({ }^{\circ} \mathrm{C}\right)$, $\mathrm{pH}$, electrical conductivity $(\mu \mathrm{s} / \mathrm{cm})$, ammonium concentration $(\mathrm{mg} / \mathrm{l})$, nitrate concentration $(\mathrm{mg} / \mathrm{l})$, chlorophyll $a$ concentration $(\mathrm{mg} / \mathrm{l})$, water volume $\left(\mathrm{m}^{3}\right)$ and aquatic invertebrates-number of taxa and biomass $(\mu \mathrm{g} / \mathrm{l})$. Water parameters were measured at a depth of $10 \mathrm{~cm}$ every 

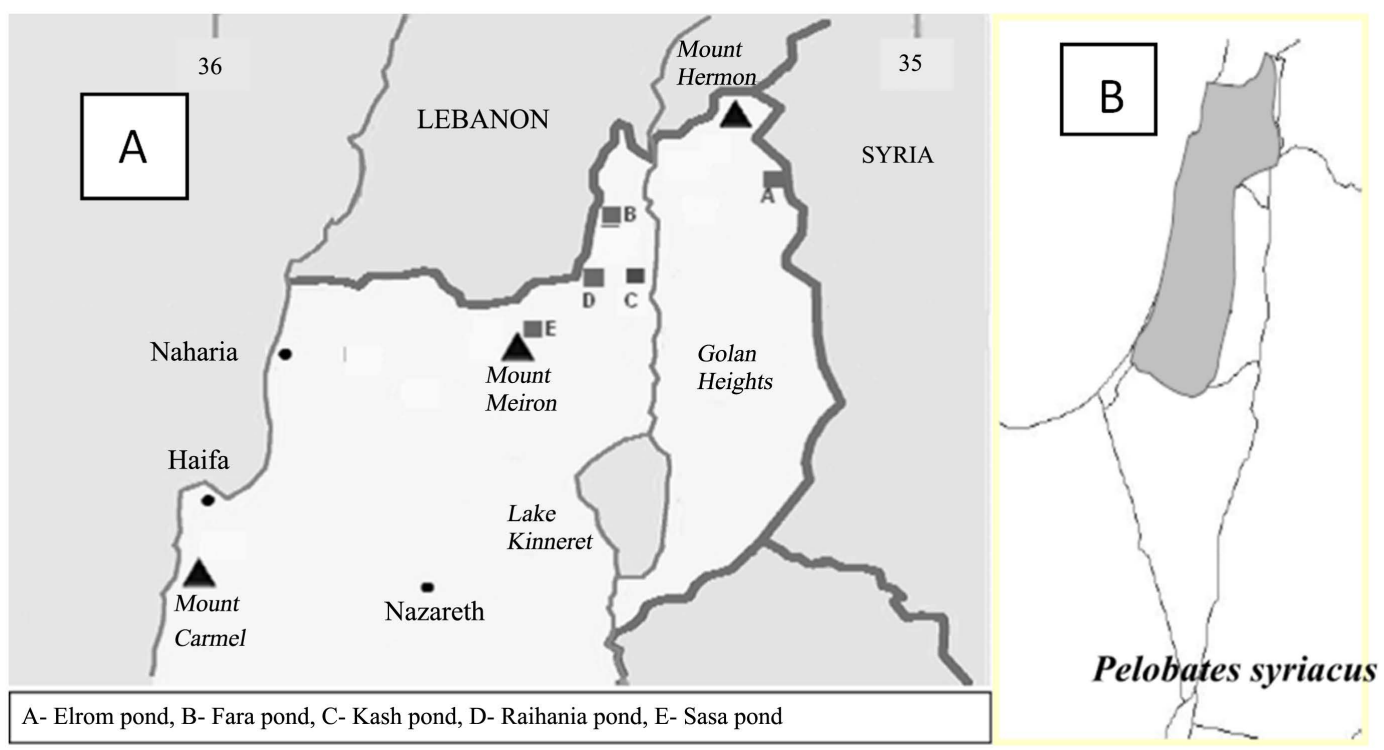

Figure 1. The study area: (A) Samples taken in different northern breeding sites of amphibians (Table 1); (B) Area in Israel where Pelobates syriacus are distributed.

two weeks during the period in which the pools were filling up. Temperature $\left({ }^{\circ} \mathrm{C}\right)$ and level of oxygen dissolved in water (dissolved oxygen concentration, $\mathrm{mg} / \mathrm{L}^{-1}$ and oxygen saturation, \%) were obtained by a hand-held oxygen meter (WTW, Oxi330 set, Germany) in situ, and one liter of water was sampled for the laboratory water quality tests, including $\mathrm{pH}$ (WTW, pH315i, Germany, electrical conductivity (EC, $\mathrm{mS} / \mathrm{cm}^{-1}$ ) corrected to $25^{\circ} \mathrm{C}$ (WTW, Multiline P4, Germany) [14], chlorophyll $a$ concentration (mg/L ${ }^{-1}$ ) extracted from GF/F filters in $90 \%$ ethanol [14], and ammonium concentrations $\left(\mathrm{NH}_{4}, \mathrm{mg} / \mathrm{L}^{-1}\right)$ carried out using kits based on color changes. Color changes were measured using a dedicated spectrophotometer (NOVA 60, Merck; Germany) [14].

\subsection{Buried Behavior Exterminate}

Fifty juvenile $P$. syriacus were collected from beneath stones in the Sasa and Dovev pond area of northern Israel during the summer (August and September) and maintained in an aquarium measuring $100 \times 30 \times 20 \mathrm{~cm}$ at the Migal Laboratory in northern Israel. In the experimental room, the temperature was maintained at $26^{\circ} \mathrm{C}$ and the aquarium was half full of moist soil. A light regime of 12 hours light and 12 hours darkness was maintained. Soil moisture level was determined according to [15]. Fully saturated soil was considered to have a moisture level of $100 \%$ and was determined in a $500 \mathrm{ml}$ glass flask half full of soil and filled with water above the soil line for $1 \mathrm{hr}$. The glass flask was turned upside down for 10 minutes in order to allow all the free water to flow out. The flask was subsequently dried in a stove for 24 hrs at a temperature of $105^{\circ} \mathrm{C}$. Full saturation was calculated according to Degani (1988).

\subsection{Terrestrial Adaption}

Ten juvenile $P$. syriacus were maintained in a $70 \%$ soil aquarium measuring $100 \times 30 \times 20 \mathrm{~cm}$ at the Migal Laboratory in northern Israel for three months, and after that period, blood samples were taken. The control group was maintained in the aquarium with $4 \mathrm{~cm}$ water for seven days and then the samples were taken. Blood samples were taken from acclimatized juveniles (tap water and burrowing juveniles) by heart puncture using micropipettes washed with lithium heparin. The blood samples were centrifuged immediately for 15 min at $300 \mathrm{~g}$, and the plasma was either analyzed immediately or frozen for analysis later. Sample preparation was according to [16]. Sodium, potassium and chloride in plasma were determined using methods described by [16]. Urea was determined using a method described by [17].

\subsection{Statistical Analysis}

The range of biotic and abiotic parameters of aquatic habitats was calculated, and average water parameters 
Table 1. Aquatic systems examined in northern Israel; Si-Salamandra infra immaculata; Tv-Triturus vittatus vittatus; Hs_-Hyla savignyi; Bv—Bufo viridis; Ps_-Pelobates syriacus; Rb-Rana bedriaga.

\begin{tabular}{|c|c|c|c|c|}
\hline Water Body & Type of Body & Galilee & $\begin{array}{c}\text { Larvae of } \\
\text { Spadefoot toads }\end{array}$ & Larvae of Amphibia \\
\hline Nimrod Pond & Winter Pond & Northern Golan & & $S i, B v$ \\
\hline Nimrod Spring & Continuous Spring & Northern Golan & & $B v$ \\
\hline Barn Pond & Winter Pond & Hula Valley & & $B v$ \\
\hline Shunit Spring & Seasonal Spring & Hula Valley & & $B v$ \\
\hline Pond North KS & Winter Pond & Hula Valley & & $B v$ \\
\hline Pond South KS & Winter Pond & Hula Valley & & $B v$ \\
\hline Nahalin Spring & Seasonal Spring & Naftali Heights & & $B v, H s$ \\
\hline Hula NR & Permanent Pond & Hula Valley & & $B v, R b$ \\
\hline Sal Pond & Winter Pond & Central Golan & & $R b, H s$ \\
\hline Katzarin Pond & Winter Pond & Central Golan & & $T v$ \\
\hline Paras Pond & Winter Pond & Central Golan & & $T v, B v, H s$ \\
\hline Surman Pond & Winter Pond & Central Golan & & $B v, H s$ \\
\hline Oil Pipe Pond & Winter Pond & Central Golan & & $B v, H s, R b$ \\
\hline Gamla Pond & Winter Pond & Central Golan & & $B v, H s$ \\
\hline Tel Bazak Pond & Winter Pond & Central Golan & & $B v, H s$ \\
\hline Darach Pond & Winter Pond & Central Golan & & $B v$ \\
\hline Sbina Pond & Winter Pond & Central Golan & & $B v, H s, R b$ \\
\hline Bageria Pond & Winter Pond & Southern Golan & & $R b$ \\
\hline Irsim Pond & Winter Pond & Southern Golan & & $R b$ \\
\hline Irism Pond North & Winter Pond & Southern Golan & & \\
\hline Nov Pond North & Winter Pond & Southern Golan & & $R b$ \\
\hline Hispin Pond & Winter Pond & Southern Golan & & $B v$ \\
\hline Shachar Pond & Winter Pond & Northern Israel & & $T v, B v, H s$ \\
\hline Kash Pond & Winter Pond & Northern Israel & & $\mathrm{Bv}, \mathrm{Hs}$ \\
\hline Dalton Pond 1 & Winter Pond & Upper Galilee & & $B v, H s$ \\
\hline Dalton Pond 2 & Winter Pond & Upper Galilee & & $B v, H s$ \\
\hline Gush Halav Pond & Winter Pond & Upper Galilee & & $S i, B v$ \\
\hline Bechania Pond & Winter Pond & Upper Galilee & & \\
\hline Sasa Pond & Winter Pond & Upper Galilee & Ps & $S i, T v, H s, B v$ \\
\hline Humama Spring & Continuous Spring & Upper Galilee & & $S i$ \\
\hline Zakin Spring & Continuous Spring & Upper Galilee & & Si \\
\hline Bet Jan Reservoir & Permanent Pond & Upper Galilee & & $S i$ \\
\hline Fasuta Pond & Winter Pond & Western Galilee & & Si \\
\hline Menachem Pond & Winter Pond & Western Galilee & & $T v, H s$ \\
\hline
\end{tabular}




\section{Continued}

\begin{tabular}{|c|c|c|c|c|}
\hline Shetula Pond & Winter Pond & Western Galilee & & \\
\hline Maron Pond & Winter Pond & Western Galilee & & $\mathrm{Si}, \mathrm{Hs}$ \\
\hline Sumara Pond & Winter Pond & Western Galilee & & Si \\
\hline Tel Arad Pond & Winter Pond & Western Galilee & & Si, Hs, Tv \\
\hline Sasa Rock Pool & Rock Pool (all year) & Upper Galilee & & Si \\
\hline Tel Dan & Continuous Stream & Northern Galilee & & Si \\
\hline Balad Spring & & & & $\mathrm{Si}, \mathrm{Hs}$ \\
\hline Navoraya Spring & & & & Si, $H s, R b$ \\
\hline Maalot Rock Pool & & & & Si \\
\hline Manof Pool & & & & $\begin{array}{c}T v, H s, \\
B v, P s S i, B v\end{array}$ \\
\hline Kash Pool & & & Ps & $S i, T v, H s, B v, R b$ \\
\hline Dovev Pool & Winter Pond & Upper Galilee & & $T v, H s, B v, P s, \mathrm{Si}$ \\
\hline \multicolumn{5}{|l|}{ Matityahu Pool } \\
\hline Lehavot Pool & & & & $H s, R b$ \\
\hline Fara Pool & & Northern Galilee & Ps & $S i, T v, H s, B v, R b$ \\
\hline Raihaniya Pool & Winter Pond & Upper Galilee & Ps & $B v$ \\
\hline Elrom Pond & Winter Pond & Northern Golan & Ps & \\
\hline
\end{tabular}

were analyzed by one-way analysis of variance (ANOVA), with the level of significance between groups set at $p$ $<0.05$ (ANOVA) (Tukey test).

\section{Results}

Spadefoot toads (Pelobates syriacus) are found in northern Israel from the north in the Upper Galilee and Golan Heights (annual rainfall range of $500-1000 \mathrm{~mm}$ ) (Figure 1), to the southern coastal plain (annual rainfall of about $250 \mathrm{~mm}$ ). Among the 51 different breeding places of amphibians, only certain ponds (Table 1) are used by Spadefoot toads and metamorphosed populations were found around those ponds. Water in the breeding places of Spadefoot toads is available for more a few months and is sometimes available all year round, the time for the larvae to grow and complete metamorphosis (Table 2). Spadefoot toads can breed several times during the warm season, usually when there is a drop in barometric pressure, two or more inches of rainfall, and in the darkness of night.

The life cycle of Spadefoot toads is presented in Figure 2. Males are the first to arrive at the pond, sending out a mating call. This call consists of a short, explosive "wonk," similar to the call of a crow. The females then arrive, and breeding occurs underwater. Breeding time in Israel varies according to location and geographical and ecological conditions. It takes place in March-April in northern Israel, Upper Galilee and the Golan Heights, and earlier in the lower locations and in central Israel. In central Israel, the breeding period is during the winter. The amplexus of Spadefoot toads involves the male holding the female above the back legs, they swim together, and the female lays 2 to 4 lies of eggs (Figure 2). The number of eggs differs, and ranges between 2000 to 10,000 per female. Larvae growth and complex metamorphosis take place in northern Israel during the summer and early autumn until October. Larvae growth in various breeding places is presented in Figure 3.

There is no information on adult terrestrial activity of Spadefoot toads. Considering the spatial distribution of rain pools and the dispersal ability of juvenile adults of only about $2-4 \mathrm{~km}$, it seems that most of the population is isolated.

The results of this experiment show that a negative correlation exists between the percentage of toads burrowing and soil moisture levels. In soil having a low moisture level (40\%), a relatively high percentage of toads 


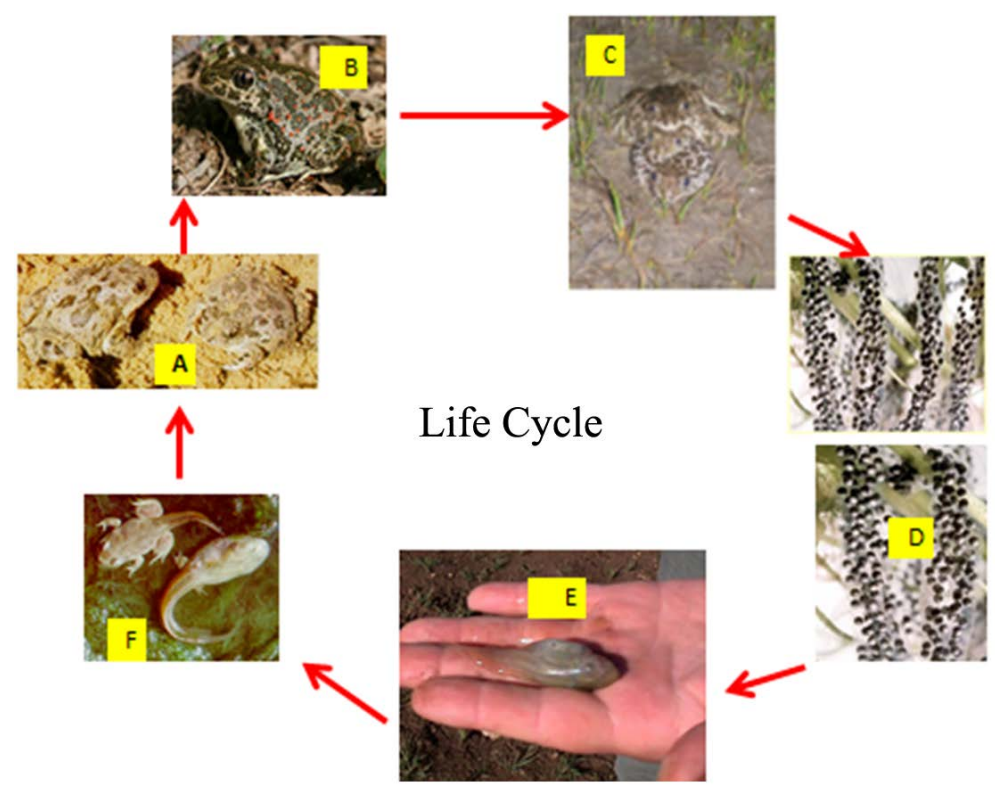

Figure 2. Life cycle of $P$. syriacus: juveniles (A) and mature females (B); Amplexuses (Cogălniceanu et al., 2013) (C); Eggs (D); Tadpole (E); Metamorphosis (F).
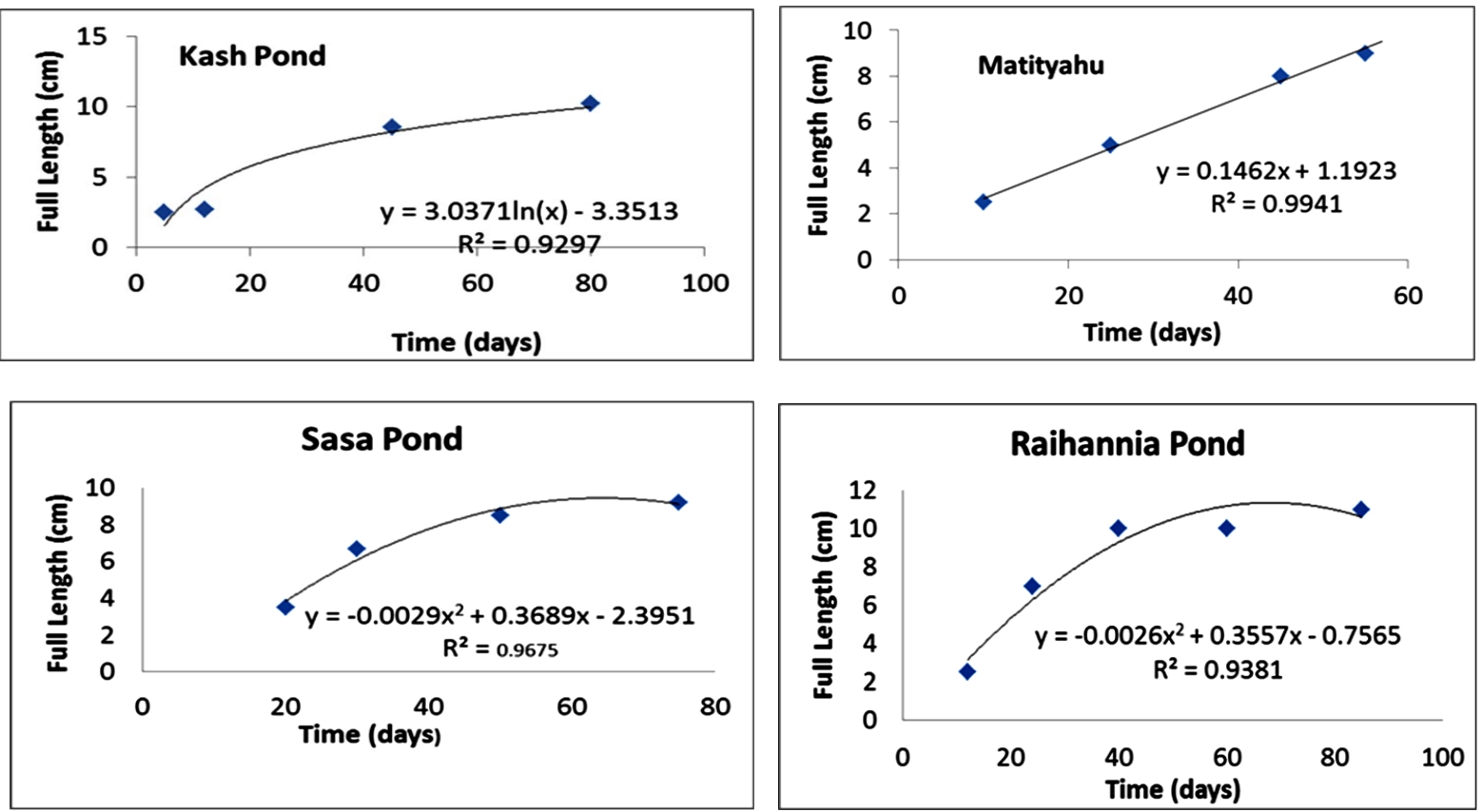

Figure 3. Growth rates of larvae of Pelobates syriacus. The Y axis shows larval size in mean of full length (cm), and the X axis shows time periods in the number of days that larvae had spent in the water body until they reached metamorphosis.

(73\%) was buried compared to a low percentage (9\%) at a high soil moisture level (100\%) (Figure 4 and Figure 5), and the concentration of plasma in the soil was higher (Figure 6). During burrowing in the soil, the urea in the plasma increased dramatically compared to other components.

\section{Discussion}

Spadefoot toads (Pelobates syriacus) are highly specialized burrowing and nocturnal species having a narrow 
Table 2. Mean values and standard deviation (SD) of biotic and abiotic water quality parameters measured in breeding sites of Pelobates syriacus.

\begin{tabular}{|c|c|c|c|c|c|c|}
\hline Site & $\begin{array}{l}\text { Taxa } \\
\text { (no.) }\end{array}$ & $\begin{array}{c}\text { Mean Biomass } \\
(\mu \mathrm{g} / \mathrm{l})\end{array}$ & $\begin{array}{c}\text { Rangechlor } \\
\text { (mg/l) }\end{array}$ & $\begin{array}{l}\text { Mean hyd } \\
\text { (days) }\end{array}$ & $\begin{array}{l}\text { Mean Max. Volume } \\
\left(\mathrm{m}^{3}\right)\end{array}$ & $\begin{array}{c}\text { Residential/ } \\
\text { Agricultural Areas }\end{array}$ \\
\hline Kash & 6 & $1.2 \mathrm{E}+05$ & $1.7-222.4$ & $172 \pm 8$ & 2335 (444) & naa \\
\hline Dovev & 8 & $3.3 \mathrm{E}+03$ & $1.9-89.2$ & $183 \pm 16$ & 278 (31) & naa \\
\hline Matityahu & 10 & $5.9 \mathrm{E}+04$ & $0.7-43.1$ & $210 \pm 4$ & 4839 (847) & naa \\
\hline Lehavot & 6 & $2.3 \mathrm{E}+04$ & $1.0-65.1$ & $130 \pm 19$ & 10272 (2291) & naa \\
\hline Sasa & 7 & $1.7 \mathrm{E}+05$ & $1.3-347.7$ & $215 \pm 18$ & 11463 (1559) & naa \\
\hline Fara & 8 & $9.6 \mathrm{E}+05$ & $0.9-581.7$ & $297 \pm 54$ & 1109 (107) & naa \\
\hline Raihania & 7 & $3.2 \mathrm{E}+05$ & $0.6-237.0$ & $271 \pm 18$ & 7956 (390) & nra/naa \\
\hline
\end{tabular}

chlor. ${ }^{a}$ chlorophyll $a$; hyd—hydroperiods; ay—all year; nra—near residential areas; naa—near agricultural areas.

\section{Burrowing Behavior}

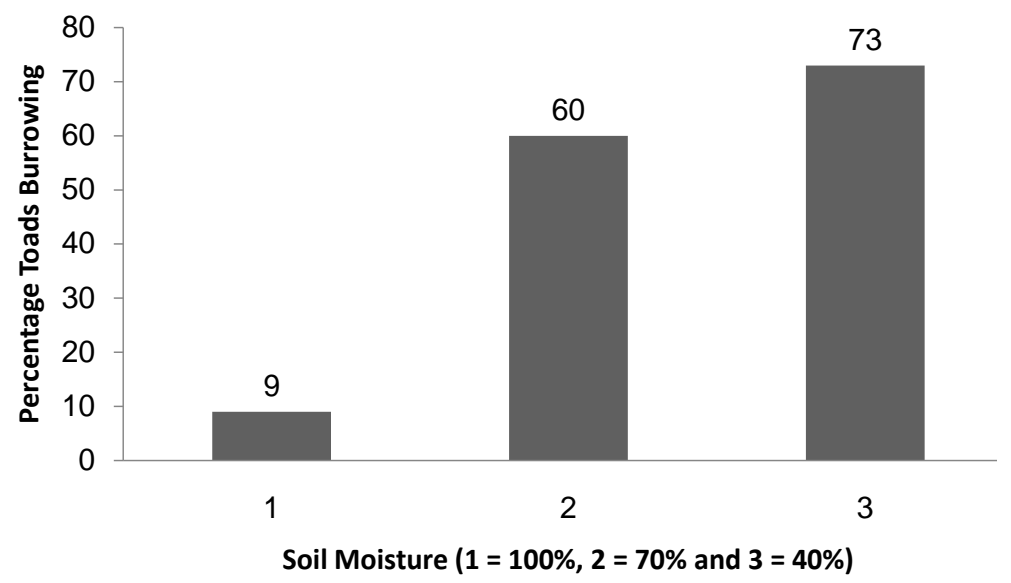

Figure 4. The effect of soil moisture on burrowing behavior of Spadefoot toads (Pelobates syriacus).

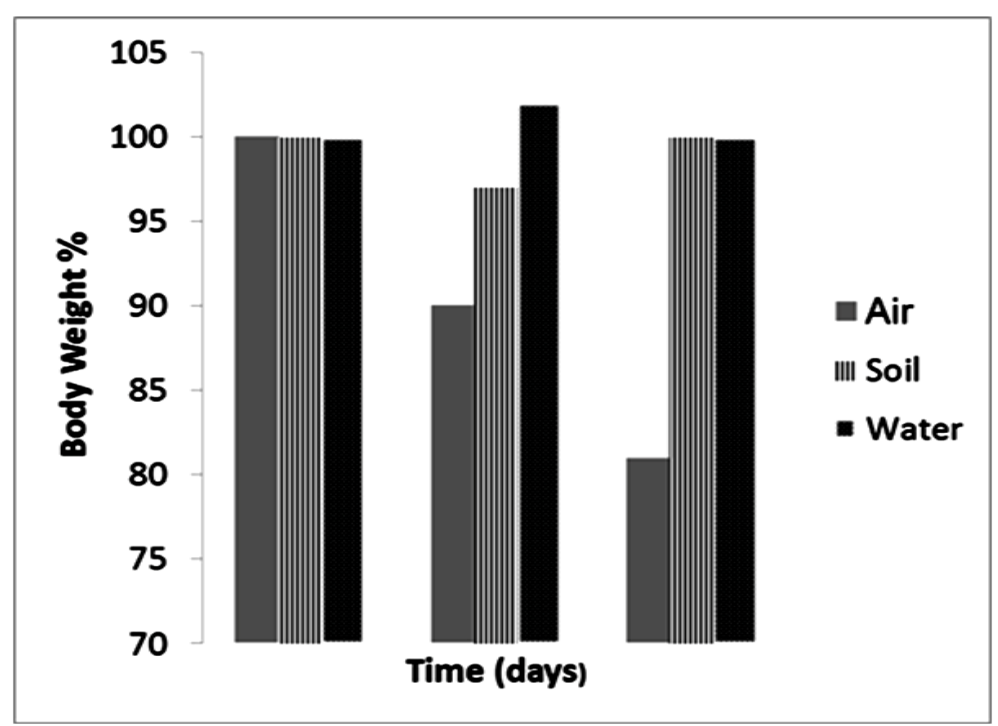

Figure 5. Spadefoot toads dehydrated under different conditions: in air, burrowed in soil and in water. 


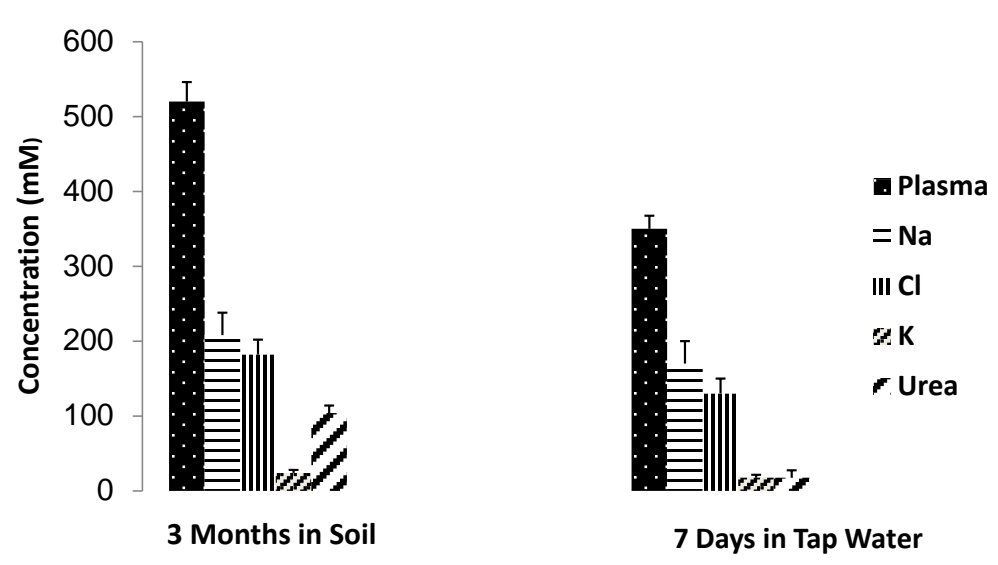

Figure 6. Changes in salinity and composition of plasma in juvenile Pelobates syriacus burrowed in soil and in water.

ecological niche among amphibians in Israel, and all of them are found in relatively extreme conditions [6]. Spadefoot toad tadpoles are the largest among Israel's amphibian species [14] [18], and the larval period can last several months until metamorphosis [4] [18], as is supported by the present study. However, the selection of breeding places included only winter ponds where water was available for a few months, as was found in Europe [1] [2] and in the present study. According to previous studies at the southern border of its distribution of larvae growth and complete metamorphosis, we suggested that the selection of ponds where water was available for a few months should be correlated to the phenomena of this species (Pelobates syriacus)—large tadpoles and long periods to complete metamorphosis, as was found in the present study and previous studies [5], and to the ecological conditions and water quality of the breeding places, e.g., the water temperature must be above $20^{\circ} \mathrm{C}$ and most of the time above $25^{\circ} \mathrm{C}$ for Spadefoot toad tadpoles to complete metamorphosis after a relatively long growth period (more than three months) [4] [5] [18].

Due to their secretive behavior (nocturnal activity, weak underwater breeding call and cryptic coloration), their adaptation to semi-arid environments is not well-documented in central Israel [8] [19] and northern Israel [6] [7] [20], and overall there is a scarcity of information regarding this genus. According to the results of the present study, the selection and adaptation to ecological conditions is not done according to the aquatic phase of Spadefoot toads but following metamorphosis. This hypothesis, which is supported by relatively many studies on the conditions of larvae growth of Spadefoot toads [14], shows that the water analysis of larvae is suitable for other amphibians in Israel, and that the distribution of Spadefoot toads is in drier conditions [21]. The burrowing behavior of metamorphosed Spadefoot toads preventing dehydration, as was found in the present study, is very important adaptation to terrestrial life. The accumulation of urea and electrolytes in the plasma during burrowing behavior seems to be a physiological adaptation, as was found in the present study, and is supported by previous research on this species [7] [22]. The only better adaptation to terrestrial life in amphibians in Israel is Green toad (Pseudepidalea viridis (Syn. Bufo viridis)) whose burrowing behavior is less than Spadefoot toads but has a higher adaptation to terrestrial life [17] [23] [24]. The other anuran in Israel, which is less adapted to terrestrial life, Hyla savygny [25] and Rana bedreagae [26], exhibits no burrowing behavior and ophiology adaptation to terrestrial life.

\section{References}

[1] Dzukic, G., Beskov, V., Sidorovska, V., Cogalniceanu, D. and Kaleziae, L.M. (2005) Historical and Contemporary Ranges of the Spadefoot Toads Pelobates spp. (Amphibia: Anura) in the Balkan Peninsula. Acta Zoologica Cracoviensia, 48A, 1-9. http://dx.doi.org/10.3409/173491505783995699

[2] Cogălniceanu, D., Székely, P., Iosif, R., Székely, D. and Stănescu, F. (2013) Life History and Conservation of Spadefoot Toads (Genus Pelobates) in Romania. FrogLog, 21, 24-26.

[3] Degani, G. and Kaplan, D. (1999) Distribution of Amphibian Larvae in Israeli Habitats with Changeable Water Availability. Hydrobiologia, 405, 49-56. http://dx.doi.org/10.1023/A:1003796820900

[4] Degani, G. (1982) Amphibian Tadpole Interaction in Winter Pond. Hydrobiologia, 96, 3-7. 
http://dx.doi.org/10.1007/BF00006274

[5] Degani, G. (1986) Growth and Behavior of Six Species of Amphibian Larvae in Winter Pond in Israel. Hydrobiologia, 140, 5-10. http://dx.doi.org/10.1007/BF00006723

[6] Degani, G. and Carmali, D. (1988) Burrowing Behavior of Pelobates syriacus. Biology of Behaviour, 13, 22-29.

[7] Degani, G., Goldenberg, S. and Warburg, M.R. (1983) Changes in Ion, Urea Concentrations and Blood Plasma Osmolarity of Pelobates syriacus Juveniles under Varying Conditions. Comparative Biochemistry and Physiology Part A: Physiology, 75, 619-623. http://dx.doi.org/10.1016/0300-9629(83)90430-9

[8] Gafny, S. (1986) The Biology and Ecology of the Syrian Spadefoot Toad Pelobates syraicus syriacus in Israel. MSc Thesis, Tel Aviv University, Tel Aviv.

[9] Gafny, S. (2004) Threatened Amphibians of Israel. In: Dolev, A. and Perevolotsky, A., Eds., Endangered Species in Israel, Red List of Threatened Animals Vertebrate, Israel Nature and Park Authority and the Society for the Preservation of Nature, Pub, Jerusalem, 55-68.

[10] Shpun, S., Huffman, J., Nevo, E. and Katz, U. (1993) Is the Distribution of Pelobates syriacus Related to Its Limited Osmoregulatory Capacity? Comparative Biochemistry and Physiology Part A: Physiology, 105, 135-139. http://dx.doi.org/10.1016/0300-9629(93)90185-7

[11] Munwes, I., Geffen, E., Roll, U., Friedmann, A., Daya, A., Tikochinski, Y. and Gafny, S. (2010) The Change in Genetic Diversity down the Core-Edge Gradient in the Eastern Spadefoot Toad (Pelobates syriacus). Molecular Ecology, 19, 2675-2689. http://dx.doi.org/10.1111/j.1365-294X.2010.04712.x

[12] Degani, G. (2013) Genetic Variation among Various Populations of Spadefoot Toads (Pelobates syriacus, Boettger, 1869) at Breeding Sites in Northern Israel. Advances in Biological Chemistry, 3, 440-447. http://dx.doi.org/10.4236/abc.2013.35047

[13] Nevo, E. (1976) Adaptive Strategies of Genetic Systems in Constant and Varying Environments. In: Karlin, S. and Nevo, E., Eds., Population Genetics and Ecology, Academic Press, New York, 141-158. http://dx.doi.org/10.1016/B978-0-12-398560-6.50011-0

[14] Goldberg, T., Eviatar, E. and Degani, G. (2009) Breeding Site Selection According to Suitability for Amphibian Larval Growth under Various Ecological Conditions in the Semi-Arid Zone of Northern Israel. Ecologia Mediterranea, 35, 65-74.

[15] Degani, G. and Warburg, M.R. (1980) The Response to Substrate Moisture of Juvenile and Adult Salamandra salamandra (L.) (Amphibia; Urodela). Biology Behaviour, 5, 281-229.

[16] Degani, G. (1981) The Adaptation of Salamandra salamandra (L.) from Different Habitats to Terrestrial Life. British Journal of Herpetology, 6, 169-172.

[17] Degani, G. (1985) Urea Tolerance and Osmoregulation in Bufo viridis and Rana ridibunda. Comparative Biochemistry and Physiology Part A: Physiology, 82, 833-836. http://dx.doi.org/10.1016/0300-9629(85)90491-8

[18] Goldberg, T., Nevo, E. and Degani, G. (2012) Amphibian Larval in Various Water Bodies in the Semi-Arid Zone. Zoological Studies, 51, 345-361.

[19] Gad, D., Thomsen, M.V. and Johannsen, H.G. (1999) [Spontaneous Rupture of the Left External Iliac Vein. A Complication of Deep Vein Thrombophlebitis?]. Ugeskrift for Lager, 161, 6639.

[20] Degani, G. and Kaplan, D. (1999) Distribution of Amphibian Larvae in Israeli Habitats with Changeable Water Availability. Hydrobiologia, 404, 49-56. http://dx.doi.org/10.1023/A:1003796820900

[21] Munwes, I., Geffen, E., Roll, U., Friedmann, A., Daya, A., Tikochinski, Y. and Gafny, S. (2010) The Change in Genetic Diversity down the Core-Edge Gradient in the Eastern Spadefoot Toad (Pelobates syriacus). Molecular Ecology, 19, 2675-2689. http://dx.doi.org/10.1111/j.1365-294X.2010.04712.x

[22] Degani, G. (1986) Osmotic Stress and Osmoregulation of Tadpoles and Juveniles Pelobates syriacus. Comparative Biochemistry and Physiology Part A: Physiology, 83, 365-370. http://dx.doi.org/10.1016/0300-9629(86)90591-8

[23] Degani, G. (1985) Osmoregulation in Red Blood Cells of Bufo viridis. Comparative Biochemistry and Physiology Part A: Physiology, 81, 451-453. http://dx.doi.org/10.1016/0300-9629(85)90163-X

[24] Degani, G., Silanikove, N. and Shkolnik, A. (1984) Adaptation of Green Toad (Bufo viridis) to Terrestrial Life by Urea Accumulation. Comparative Biochemistry and Physiology Part A: Physiology, 77, 585-587. http://dx.doi.org/10.1016/0300-9629(84)90233-0

[25] Degani, G., Nagar, R. and Yom-Din, S. (2012) Molecular DNA Variation in Hyla felixarabica. Herpetol. Romanica, 6, 51-67.

[26] Degani, G., Goldberg, T. and Yom-Din, S. (2013) The Ecology and Variation in DNA of Rana bedreagae from Various Breeding Site in North Israel. Res. Open. J. Anim. Sci, 1, 1-14. 